\title{
Pengaruh Komposisi Media Tanam dan Dosis NPK Terhadap Pertumbuhan Stek Kantong Semar (Nepenthes ampullaria Jack)
}

\author{
M. Kurniawan Candra, S. Hut, MP. 1), Sumjulia 2) \\ 1). Staf Pengajar Prodi Kehutanan 2) Mahasiswa Prodi Kehutanan \\ Fakultas Pertanian Universitas Kapuas Sintang \\ Email : candra.kurniawanmuhammad@gmail.com
}

\begin{abstract}
Abstrak. Kantong Semar merupakan tumbuhan yang mempunyai nilai estetika tinggi. Salah satu Kantong Semar yang memiliki nilai estetika serta banyak digemari oleh para pecinta tumbuhan hias adalah kantong semar (Nepenthes ampullaria Jack). Meskipun jumlahnya cukup banyak di alam, namun apabila tidak ada upaya untuk melestarikan dan membudayakannya, dikhawatirkan jenis ini menjadi punah. Hal ini dapat terjadi karena tingginya nilai komersil dari kantong semar tersebut. Sehingga memicu masyarakat untuk memanfaatkannya tanpa terkendali, serta adanya upaya pengelolaan hutan yang tidak berwawasan lingkungan. Penelitian ini dilakukan dengan mengunakan Rancngan Acak Lengkap (RAL) yang terdiri dari 2 faktor, masing-masing factor terdiri dari 3 taraf perlakuan dan 3 kali taraf ulangan. Factor pertama adalah media tanam kokopit dan sekam bakar, factor kedua adalah dengan dosis pupuk NPK. Analisis yang digunakan adalah Analis Sidik Ragam, selanjutnya untuk mengetahui untuk mengetahui perbedaan perlakuan digunakan Uji Beda Nyata Jujur (BNJ) pada taraf perlakuan 5\% dan 1\%. Dari hasil penelitian tentang pengaruh komposisi media dan dosis NPK terhadap pertumbuhan stek kantong semar Nepenthes ampularia Jack diketahui bahwa perlakuan komposisi media tidak signifikan terhadap panjang akar, jumlah tunas dan panjang tunas, sedangkan interaksi komposisi media 75\%kokopit dengan 25\% sekam bakar (K1n1) dan dosis NPK 0,5 gram hanya signifikan pada jumlah tunas tanaman Nepenthes ampularia Jack. Dan tidak signifikan pada panjang akar dan panjang tunas.
\end{abstract}

Kata kunci : Media tanam, Pupuk NPK dan Kantong Semar

\section{PENDAHULUAN}

Pembangunan

kehutanan

merupakan upaya menjaga dan

melestarikan hutan secara lesteri dan sebesar-besarnya untuk kemakmuran rakyat yang berkeadilan serta berkelanjutan. Sedangkan yang dimaksud dengan hutan adalah salah satu kesatuan ekosistem berupa hamparan berisi sumber daya alam hayati yang didominasi oleh pepohonan dalam persekutuan alam lingkunagn yang satu dengan yang lainnya tidak dapat dipisahkan (Undang-undang Republik Indonesia Nomor 41 tahun 1999 tentang Kehutanan).

Kantong Semar belakangan ini telah mencapai popularitas yang sangat luar biasa. Bentuk, warna dan sifatnya yang unik sangat menarik perhatian, terutama oleh pecinta tanaman hias. Kondisi seperti ini mendorong minat para pecinta tanaman hias untuk melakukan ekploitasi dalam skala besar 
dari habitat alaminya yang dapat mengakibatkan keberadaan tumbuhan Nepenthes ampullaria Jack menjadi punah. Keadaan seperti ini harus dilakukan suatu upaya konservasi.

Kantong Semar memiliki perakaran sedikit dibandingkan tanaman lainnya, pertumbuhan akan baik jika media tanamnya memiliki aerasi cukup tinggi, tidak padat, tidak banyak menyimpan air dan proses dekomposisinya lambat. Ada beberapa macam media yang dapat digunakan antara lain kokopit dengan sekam bakar.

Dengan komposisi kedua komponen tersebut media tanam menjadi tidak mudah padat, tingkat aerasi dan porositas menjadi tinggi sehingga akar tanaman dapat bersifat dengan baik.

\section{METODOLOGI PENELITIAN}

\section{Rancangan Penelitian}

Penelitian ini mengunakan metode eksperimen lapangan dalam bentuk faktorial dengan pola dasar Rancangan Acak Lengkap (RAL), dengan alasan bibit dan perlakuan yang diberikan seragam (homogen). Perlakuan terdiri dari 2 faktor yaitu komposisi media dan dosis NPK. Komposisi media (K) terdiri dari 3 taraf dan dosis NPK (N) terdiri dari 3 taraf sehingga didapat sebanyak 9 kombinasi perlakuan masing-masing dengan 3 kali ulangan. Faktor I adalah komposisi media dari 3 taraf, yaitu $\mathrm{K}_{1}=$ 75\% kokopit dengan 25\% sekam bakar, $\mathrm{K}_{2}=50 \%$ kokopit dengan $50 \%$ sekam bakar dan $\mathrm{K}_{3}=25 \%$ kokopit dengan 75\% sekam bakar. Faktor II dosis NPK terdiri dari 3 taraf, yaitu $\mathrm{n}_{1}=0,5$ gram/liter, $\mathrm{n}_{2}=1,0$ gram/liter dan $\mathrm{n}_{3}=$ 1,5 gram/liter. Satuan pengamatan dalam penelitian ini terdiri dari 4 tanaman dalam tiap petak percobaan, sehingga jumlah keseluruhannya adalah 3 ulangan $\times 9$ kombinasi $\times 4$ tanaman = 108 tanaman.

\section{Bahan dan Alat Penelitian}

Bahan-bahan yang digunakan dalam penelitian ini adalah :

1. Kokopit, yaitu serabut kelapa yang dihaluskan sehingga menjadi serbuk, digunakan sebagai media tanam.

2. Sekam bakar, yaitu ampas padi yang telah dibakar, digunakan sebagai media tanam.

3. Pupuk NPK, digunakan sebagai bahan percobaan.

4. Tanaman Nepenthes ampullaria Jack, digunakan sebagai bahan penelitian 
5. Gelas plastik, berukuran diameter 9 $\mathrm{cm}$ dan tinggi $13 \mathrm{~cm}$ yang dasar dan dindingnya telah dilubangi, digunakan sebagai wadah tanaman.

6. Bilah bambu, papan, kasau dan reng digunakan untuk membuat naungan.

7. ZPT Grow more digunakan sebagai zat perangsang akar.

8. Air digunakan untuk menyiram tanaman.

Alat-alat yang digunakan antara lain adalah:

1. Gunting stek, digunakan untuk memotong batang tumbuhan Nepenthes ampullaria,Jack.

2. Parang, digunakan untuk membersihkan lokasi penelitian dan membuat naungan.

3. Gembor, digunakan untuk menyiram tanaman.

4. Palu dan paku, digunakan untuk membuat naungan.

5. Kamera, digunakan untuk mendokumentasikan kegiatan penelitian

6. Mistar, digunakan untuk mengukur bagian akar dan panjang tunas stek.

7. Alat tulis menulis, digunakan untuk mencatat semua kegiatan penelitian.

\section{Pelaksanaan Penelitian}

1. Persiapan Lahan

Lahan dibersihkan dari rumput dan semak belukar, kemudian dibuatkan tempat untuk menyusun wadah tanaman dari gelas plastik yang telah diisi media. Bentuk ukuran disesuaikan dengan kondisi lahan dan pola penelitian.

2. Pembuatan Tempat Penelitian

Pembuatan tempat penelitian dilakukan pada awal panelitian dengan mengunakan kasau, reng dan papan serta atap naungan dari bilah bambu. Tujuan pembuatan tempat penelitian ini adalah untuk meletakan stek Nepenthes ampullaria Jack yang sudah dimasukan dalam gelas plastik agar terhindar dari pertumbuhan gulma dan ganguan dari binatang ternak yang dapat menggangu pertumbuhan stek Nepenthes ampullaria Jack. Atap naungan berbentuk datar dengan menghadap kearah Utara, membelakangi selatan serta membujur arah timur dan barat.

\section{Penyiapan Media Tanam}

Media tanam yang terdiri dari kokopit dan sekam bakar. Kokopit yang digunakan berbentuk 
kepingan bulat. Selanjutnya,

dihancurkan dengan cara di rendam

kedalam air, kokopit yang sudah direndam barulah dapat dikombinasikan dengan sekam bakar dengan perbandingan berdasarkan takaran yang sudah ditentukan.

4. Memperbanyak Tanaman

Tanaman yang telah diambil dari habitat aslinya dipotong dengan mengunakan gunting stek dengan kemiringan $45^{\circ}$. Stek batang dilakukan pada tanaman yang telah dewasa sepanjang kurang lebih $15 \mathrm{~cm}$ dengan 3-4 ruas. Helai daun dipotong setengahnya untuk mengurangi penguapan.

5. Penanaman

Penanaman dilakukan secara serentak dengan menanam stek dalam gelas plastik, sebelum ditanam bekas luka potongan bagian bawah terlebih dahulu direndam dengan perangsang penumbuh akar mengunakan Rapid Root, bagian atas luka ditutup mengunakan plastik.

6. Penyiraman

Penyiraman dilakukan dua kali sehari pagi dan sore sesuai dengan kebutuhan tanaman. Penyiraman tidak boleh berlebihan karena akan mengakibatkan munculnya bakteri atau jamur.

7. Pemupukan

Pemberian pupuk mulai dilakukan setelah sek tanaman berumur 2 (dua) minggu dengan frekuensi dua minggu sekali. Sehingga selama dalam penelitian pemupukan diberikan sebanyak 3 (tiga) kali.

8. Pemeliharaan

Pemeliharaan dilakukan dengan membersihkan tanaman dari hama atau gulma yang ada.

\section{Tempat dan Waktu Penelitian}

Tempat penelitian dilakukan di lahan yang ada di rumah Peneliti yang terletak di Jalan Y.C. Oevang Oeray. Penelitian ini dilakukan dalam kurun waktu 82 hari, yaitu dari awal bulan Mei, Juni sampai dengan bulan Juli 2013.

\section{HASIL DAN PEMBAHASAN}

\section{Hasil Penelitian}

Berdasarkan hasil penelitian yang telah dilakukan, pengaruh Komposisi Media dan Pengaruh Pupuk NPK dan interaksi antara Komposisi Media dan 
Pengaruh Pupuk NPK terhadap Panjang

Akar, Jumlah Tunas dan Panjang Tunas, stek Nepenthes Ampullaria Jack dapat

dijelaskan sebagai berikut

\section{Panjang Akar Tanaman Nepenthes Ampullaria Jack}

Table 1. Analisis Keragaman panjang akar tanaman Nepenthes Ampullaria Jack, selama penelitian.

\begin{tabular}{|l|c|r|r|c|c|c|}
\hline \multirow{2}{*}{ SK } & \multirow{2}{*}{ DB } & \multirow{2}{*}{ JK } & \multirow{2}{*}{ KT } & \multirow{2}{*}{ F. HIT } & \multicolumn{2}{c|}{ F. Tabel } \\
\cline { 6 - 7 } & & & & & $5 \%$ & $1 \%$ \\
\hline Ulangan & 2 & 5.29 & 2.65 & $0.50^{\text {th }}$ & 3.63 & 6.23 \\
\hline Perlakuan & 8 & 383.31 & 47.91 & $0.13^{\text {th }}$ & 2.59 & 3.89 \\
\hline Komposisi Media & 2 & 379.66 & 189.83 & $0.50^{\text {th }}$ & 3.63 & 6.23 \\
\hline Dosis NPK & 2 & 364.57 & 182.29 & $0.50^{\text {th }}$ & 3.63 & 6.23 \\
\hline Interaksi & 4 & -360.92 & -90.23 & $0.25^{\text {th }}$ & 3.01 & 4.77 \\
\hline Galat & 16 & 47.4 & 2.96 & \multicolumn{5}{|c|}{ KK=0,71 } \\
\hline Total & 26 & 436.00 & \multicolumn{5}{|c}{} \\
\hline
\end{tabular}

Keterangan: $\mathbf{t n}=$ berpengaruh tidak nyata

Tabel analisis keragaman diatas menunjukan tidak adanya pengaruh yang signifikan dari komposisi media dan pemberian pupuk NPK terhadap panjang akar tanaman Nepenthes
Ampullaria Jack, selama penelitian dalam kurun waktu 82 hari. Selanjutnya maka tidak perlu dilakukan uji lanjutan yaitu Uji Beda Nyata Jujur (BNJ).

\section{Jumlah Tunas Tanaman Nepenthes Ampullaria Jack}

Tabel 3. Analisis Keragaman Jumlah Tunas tanaman Nepenthes Ampullaria Jack, selama penelitian.

\begin{tabular}{|l|r|r|r|r|r|c|}
\hline \multirow{2}{*}{ SK } & \multirow{2}{*}{ DB } & \multirow{2}{*}{ JK } & \multirow{2}{*}{ KT } & \multirow{2}{*}{ F. HIT } & \multicolumn{2}{c|}{ F. Tabel } \\
\cline { 6 - 8 } & & & & & $5 \%$ & $1 \%$ \\
\hline Ulangan & 2 & 0.56 & 0.28 & $0.03^{\text {tn }}$ & 3.63 & 6.23 \\
\hline Perlakuan & 8 & 66.39 & 8.30 & $0.67^{\text {tn }}$ & 2.59 & 3.89 \\
\hline Komposisi Media & 2 & 24.74 & 12.37 & $0.91^{\text {tn }}$ & 3.63 & 6.23 \\
\hline Dosis NPK & 2 & 27.11 & 13.56 & $3.73^{*}$ & 3.63 & 6.23 \\
\hline Interaksi & 4 & 14.53 & 3.6325 & $15.29^{* *}$ & 3.01 & 4.77 \\
\hline Galat & 16 & 3.8 & 0.24 & \multicolumn{5}{|c|}{ KK=0.55 } \\
\hline Total & 26 & 70.75 & \multicolumn{5}{|c}{} \\
\hline
\end{tabular}

Keterangan: $\quad$ tn $=$ berpengaruh tidak nyata

* = berpengaruh nyata pada taraf $5 \%$

$* *=$ berpengaruh sangat nyata pada taraf $1 \%$ 
Tabel analisis keragaman diatas menunjukan tidak adanya pengaruh yng singnifikan dari komposisi media terhadap jumlah tunas tanaman Nepenthes Ampullaria Jack, selama penelitian dalam kurun waktu 82 hari. Namun pada pemberian pupuk NPK, berpengaruh nyata pada taraf $5 \%$. sedangkan interaksinya memberikan pengaruh yang sangat signifikan pada jumlah tunas tanaman Nepenthes Ampullaria Jack baik itu pada taraf 5\% maupun pada taraf $1 \%$. Selanjutnya dilakukan Uj Beda Nyata Jujur (BNJ) dapat dilihat pada table berikut ini :

Tabel 4. Uji Beda Nyatta Jujur (BNJ) pengaruh media dan dosis NPK terhadap pertumbuhan Jumlah Tunas tanaman Nepenthes ampullaria Jack usua 82 hari.

\begin{tabular}{|c|c|c|c|c|}
\hline Perlakuan & Rerata & \multicolumn{3}{|c|}{ Beda dengan } \\
\hline K1n1 & 10.69 & $\ldots \ldots \ldots$ & & \\
\hline K2n2 & 13.62 & $2.96^{* *}$ & $\ldots \ldots \ldots$ & \\
\hline K3n3 & 17.69 & $4.07^{* *}$ & $1.11^{* *}$ & $\ldots \ldots \ldots$ \\
\hline BNJ 5\% = 0.58 & & BNJ 1\% & \\
\hline
\end{tabular}

Ket: $* *=$ Berpengaruhnyata Pada taraf $5 \%$ dan $1 \%$

\section{Panjang Tunas Tanaman Nepenthes Ampullaria Jack}

Tabel 5. Analisis Keragaman Panjang Tunas tanaman Nepenthes Ampullaria Jack, selama penelitian.

\begin{tabular}{|l|r|r|r|c|c|c|}
\hline \multirow{2}{*}{ SK } & \multirow{2}{*}{ DB } & \multirow{2}{*}{ JK } & \multirow{2}{*}{ KT } & \multirow{2}{*}{ F. HIT } & \multicolumn{2}{c|}{ F. Tabel } \\
\cline { 6 - 8 } & & & & & $5 \%$ & $1 \%$ \\
\hline Ulangan & 2 & 0.67 & 0.335 & $0.01^{\text {tn }}$ & 3.63 & 6.23 \\
\hline Perlakuan & 8 & 263.59 & 32.95 & $0.40^{\text {tn }}$ & 2.59 & 3.89 \\
\hline Komposisi Media & 2 & 164.54 & 82.27 & $1.74^{\text {tn }}$ & 3.63 & 6.23 \\
\hline Dosis NPK & 2 & 94.31 & 47.16 & $39.79^{* *}$ & 3.63 & 6.23 \\
\hline Interaksi & 4 & 4.74 & 1.185 & $0.56^{\text {tn }}$ & 3.01 & 4.77 \\
\hline Galat & 16 & 33.57 & 2.10 & \multicolumn{5}{|c|}{ KK=0.91 } \\
\hline Total & 26 & 297.83 & \multicolumn{5}{c}{} \\
\hline
\end{tabular}

Keterangan: $\quad \mathbf{t n}=$ berpengaruh tidak nyata

$* *$ = berpengaruh sangat nyata pada taraf $1 \%$ 
Tabel analisis keragaman di atas menunjukan tidak adanya pengaruh yang signifikan dari komposisi media dan interaksinya terhadap panjang tunas tanaman Nepenthes Ampullaria Jack, selama penelitian dalam kurun waktu 82 hari. Namun pada pemberian pupuk
NPK, memberikan pengaruh yang sangat nyata pada panjang tunas tanaman Nepenthes Ampullaria Jack baik itu pada taraf 5\% maupun pada taraf $1 \%$. Selanjutnya dilakukan pengujian Beda Nyata Jujur pada taraf $5 \%$ dan $1 \%$ sebagai berikut :

Tabel 6. Uji Beda Nyata Jujur (BNJ) pengaruh dosis NPK terhadap pertumbuhan Panjang Tunas tanaman Nepenthes ampullaria Jack usua 82 hari

\begin{tabular}{|c|c|c|c|c|}
\hline Perlakuan & Rerata & \multicolumn{3}{|c|}{ Beda dengan } \\
\hline $\mathrm{n} 1$ & 15.28 & $\ldots \ldots \ldots$ & & \\
\hline $\mathrm{n} 2$ & 26.47 & $11.19 * *$ & $\ldots \ldots \ldots$ & \\
\hline $\mathrm{n} 3$ & 33.24 & $6.77 * *$ & $-4.42 \mathrm{tn}$ & $\ldots \ldots \ldots$ \\
\hline BNJ 5\% $=1.74$ & & & BNJ $1 \%=2.99$ \\
\hline
\end{tabular}

Ket: $* *=$ Berpengaruhnyata Pada taraf $5 \%$ dan $1 \%$

tn = Tidak berpengaruhnyata

\section{Pembahasan}

Media sangat erat hubungannya dengan perkembangan perakaran stek karena media berhubungan langsung dengan bagian yang membentuk perakaran. Media yang digunakan dalam penelitian ini adalah campuran kokopit dan arang sekam (75:25). Menurut Radian (2000) bahwa setiap unsur hara memiliki peranan spesifik dalam tanaman, namun demikian ada beberapa unsur yang berperan ganda. Karena setiap unsur berperanan khusus, maka suatu keadaan defisit atau berlebihan umumnya akan mengakibatkan gejala khas. Gejala inilah yang disebut dengan defisiensi.

Nitrogen berperan dalam pertumbuhan vegetatif tanaman terutama daun, unsur posfor (P) berperan dalam pertumbuhan akar, dalam hal perbanyakan dan perpanjangan, sedangkan kalium (K) berperan dalam pertumbuhan bagian generatif (bunga dan buah). Walaupun media ini mempunyai kandungan $\mathrm{N}$ total yang sangat rendah yaitu $1,07 \%$ tetapi stek menunjukan pertumbuhan 
yang baik. Menurut Hukum Minimum yang dikemukakan oleh Justus Von Liebing (1862) sebagian dikutip Mahrini (2006) menyatakan "pertumbuhan dan perkembangan tanaman akan demikian tergantung dari ketersediaan unsur hara esensial yang berada dalam keadaan minimum". Dimana unsur yang paling kecil kandungannya dalam tanah akan sangat menentukan dan berpengaruh terhadap pertumbuhan tanaman.

$\begin{array}{lccc}\text { Kapasitas Tukar } & \text { Kation } & \text { (KTK) } \\ \text { adalah kemampuan } & \text { suatu } & \text { unsur } \\ \text { berikatan dengan } & \text { unsur } & \text { lain. }\end{array}$

Berdasarkan hasil analisis media, KTK media kokopit dan sekam bakar sangatlah tidak signifikan pada taraf 5\% dan $1 \%$ berarti kemampuan unsur yang ada pada media untuk berikatan dengan unsur lain sangat rendah. Berbeda halnya dengan NPK dan interaksinya.

Usaha dan upaya manusia dalam memuliakan tanaman sangat beragam, dan tidak jarang pula mengalami kegagalan. Dalam penelitian ini media yang digunakan ialah media kokopit dan sekam bakar, dalam kenyataannya bahwa meskipun telah dilakukan kombinasi antara kedua media ini ternyata, hasil yang yang ditunjukan tidak memberikan pengaruh yang nyata pada panjang akar, jumlah tunas dan panjang tunas Nepenthes ampullaria Jack.

Ada tiga cara untuk memperbanyak Nepenthes yaitu dengan cara Stek, Biji dan Kultur Jaringan. Tetapi yang tingkat keberhasilannya paling tinggi adalah dengan cara stek (Anonim 2006). Suatu pernyataan memang selalu mengundang penasaran yang mendalam, oleh karena itu perlu untuk dilakukan pembuktian. Dalam penelitian ini, Penulis mengambil cara stek. Stek sebaiknya berasal dari induk yang berumur relatif sama. Dengan persamaan umur inilah, diameter dan panjang akar relatif sama sehingga jumlah auxsin dan karbohidrat yang terkandung didalamnya akan sama pula, hal ini pun akan memberikan respon yang seragam terhadap perlakuan.

Faktor inilah yang sulit dipenuhi dalam penelitian, karena sangat sulit mengatur umur dari induk karena tumbuh secara alami. Hal inilah yang menyebabkan pertumbuhan tidak seragam dan mempunyai koefisien keragaman yang tinggi pada analisis ragam. Dengan satuan pengamatan yang meliputi, panjang akar, jumlah 
tunas dan panjang tunas pada tanaman

Nepenthes ampullaria Jack.

1. Panjang akar

Nepenthes

ampullaria Jack

Secara fisiologi, panjang pendeknya batang (ruas) mempengaruhi jumlah cadangan makanan (karbohidrad) yang ada di dalamnya, sehingga berpengaruh terhadap kecepatan tumbuh stek untuk membentuk akar. Jumlah ruas juga mempengaruhi banyaknya auksin yang ada pada batang, sehingga berpengaruh pada kecepatan tumbuh stek, di sisi lain jumlah ruas juga menunjukan jumlah daun yang tertinggal, hal ini berarti juga berhubungan erat dengan besar kecilnya penguapan yang terjadi.

Menurut Wudianto (2006), dengan menyisakan daun diharapkan akan dapat melakukan pengolahan bahan makanan sehingga dapat mempercepat pertumbuhan akar. Salisburi dan ross sebagaimana dikutip Tjitrosoepomo (1985) mengemukakan bahwa jika daun muda dan kucup (yang kaya akan auksin) dipangkas, jumlah pembentukan akar samping berkurang, namun bila hilangnya organ tersebut digantikan dengan auksin, maka kemampuan membentuk akar akan pulih kembali.
2. Jumlah tunas

Pada table 4 analisis ragam menunjukan pemberian NPK memberikan pengaruh pada taraf 5\% sedangakan interaksi antara media dan NPK menunjukan pengaruh yang sangat signifikan pada taraf $1 \%$ terhadap pertumbuhan jumlah tunas. hal ini menunjukkan bahwa media kokopit dan sekam bakar serta pemberian NPK sangat baik untuk digunakan dalam hal pertumbuhan Nephenthes ampullaria jack. Jumlah ruas juga menunjukan panjang atau pendeknya stek yang ditanam, jumlah ruas juga menunjukan jumlah tunas yang akan tumbuh karena pada masing-masing ruas terdapat mata tunas.

\section{Panjang tunas}

Pada tabel 5 pemberian NPK pada stek tanaman Nepenthes ampularia Jack, ternyata memberikan pengaruh yang sangat nyata untuk menunjang pertumbuhan panjang tunas. Sedangkan media kokopit dan sekam bakar serta interaksinya tidak memberikan pengaruh yang signifikan dalam pertumbuhan panjang tunas Nepenthes ampularia Jack. Hal ini menunjukan peranan NPK memberikan manfaat dalam memenuhi kebutuhan 
akan makan sangai baik bagi tanamam stek Nepenthes ampularia Jack. Pemberian NPK kedalam media tumbuh tanaman nepenthes ampularia jack pada dosis yang tepat akan membantu dalam pertumbuhan panjang tunas.

\section{Perlakuan stek sebelum ditanam}

Stek yang diambil dari lapangan harus dilakukan perlakuan sebelum di angkut ke kebun penanaman. Perlakuan yang dilakukan adalah dengan membasahi bahan stek kemudian dimasukan kedalam kantong plastik transparan.

\section{Suhu}

Menurut anonim, stek sebaiknya diletakan pada tempat yang ternaungi dan tidak terkena cahaya matahari secara langsung. Hal ini penting mengingat pada masa ini stek belum menjadi individu yang mempunyai organ yang lengkap sehingga jika terkena cahaya matahari secara langsung maka akan terjadi penguapan yang berlebihan sehingga stek akan layu dan mati. Ditambah oleh (rochiman dan Harjadi, 1973) stek memerlukan perlindungan dari cahaya matahari langsung untuk mempertahankan temperatur dan kelembapan. Peran cahaya terutama dalam pembentukan auksin dan karbohidrat.

Suhu di lokasi penelitian Nepenthes ampullaria Jack ini berkisar antara 20-35 ${ }^{\circ} \mathrm{C}$, dengan kelembaban udara rata-rata $70 \%$, sedangkan suhu di persemaian pada saat penelitian dengan rata-rata $24-30^{\circ} \mathrm{C}$ dengan kelembapan udara 69,38\%, sehingga apabila dibandingkan dengan habitat aslinya suhu di persemaian pada saat penelitian jelas lebih tinggi.

Hal inilah yang menjadi salah satu kendala keberhasilan stek, namun ada stek yang bisa menyesuaikan diri (survive) dengan kondisi lingkungan seperti ini karena beberapa hal diantaranya tua atau mudanya stek (umur), kandungan makanan yang ada didalamnya serta ada tidaknya mata tunas sebagai bakal tunas.

Menurut Hendaryono, (1998:39) kelembaban udara atau humidity dapat menjadi faktor penghambat dalam pertumbuhan tanaman, apabila dalam keadaan yang sangat tinggi. Oleh karena itu perlu untuk diperhatikan secara seksama, menginggat bahwa suatu tanaman apabila dalam suhu yang terlalu tinggi akan mudah terserang oleh cendawan. Kelembaban udara dapat ditentukan dengan membandingkan uap 
air didalam udara dengan jumlah uap air maksimal yang dapat ditahan oleh udara pada suhu tertentu.

Kelembaban yang terlalu tinggi akan mendatangkan kerusakan bagi pertumbuhan tanaman Nepenthes ampullaria Jack. Akar menjadi busuk sebab jamur terstimular pertumbuhannya. Demikian juga, bakteri dalam waktu yang cepat dapat menyebar ke seluruh bagian akar tanaman. Akibatnya, akar tidak dapat berfungsi sebagai penyerap unsur hara, sehingga tanaman mengalami defisiensi unsur hara yang dapat mengakibatkan kematian tanaman.

\section{KESIMPULAN DAN SARAN}

\section{Kesimpulan}

Berdasarkan hasil penelitian tentang pengaruh komposisi media dan dosis NPK terhadap pertumbuhan stek kantong semar Nepenthes ampullaria Jack selama 3 bulan dapat diambil beberapa kesimpulan :

1. Komposisi media tanam tidak berpengaruh terhadap pertumbuhan panjang akar, jumlah tunas dan panjang tunas. Sedangkan NPK berpengaruh terhadap jumlah tunas dan panjang tunas.
2. Interaksi komposisi media $70 \%$ kokopit dengan $25 \%$ sekam bakar dan dasis NPK 0,5 gram/literK1n1 dan dosis NPK 0,5 gram hanya signifikan pada jumlah tunas tanaman Nepenthes ampullaria jack. Dan tidak signifikan pada panjang akar dan panjang tunas.

3. Komposisi media k1n1 (75\% kokopit dengan $25 \%$ sekam bakar) dan dosis NPK 0,5gram adalah yang terbaik dalam mempengaruhi panjang tunas.

\section{Saran}

Sebelum melakukan berbanyakan suatu tanaman (dengan cara stek, cangkok, grfting, layering dan sebagainya) termasuk stek kantong semar Nepenthes ampullaria Jack disarankan untuk mengunakan bahan yang mempunyai umur dan panjang yang sama. Selain itu dalam pemilihan bahan stek sebaiknya memperhatikan ada atau tidaknya bakal mata tunas yang nantinya akan menjadi tunas, hal ini penting karena bila bakal tunas dalam keadaan dormansi (istirahat) maka proses bertunasnya akan lama. Adapun cara yang paling sederhana untuk melihat aktif atau tidaknya bakal tunas yaitu bila terdapat atau tidaknya 
benjolan pada ketiak daun.

Pemberian NPK dalam menunjang pertumbuhan jumlah tunas dan panjang tunas pada tanaman Nepenthes ampularia Jack sangatlah di anjurkan dalam dosis 1,5 gram/ liter. Komposisi media dan dosis NPK yang sama dapat dilakukan penelitian ulang pada jenis Nepenthes yang berbeda.

\section{DAFTAR PUSTAKA}

Antonius, 2008. Studi Keanekaragaman Jenis Kantong Semar (Nepenthes Sp). Kawasan Bukit Kelingkang Kabupaten Sintang. Skripsi Jurusan Kehutanann Fakultas Pertanian Universitas Kapuas Sintang.
Charles, C 1997. Nepenthes of Borneo. Natural History Publication, sabah.

Gasperz, V. 1991. Rancangan Percobaan. Jakarta: Armico.

Lingga, P. 1986. Petunjuk Pengunaan Pupuk. Penebar Swadaya.

Mansur, M. 2006. Nepenthes Kantong Semar Yang unik. Jakarta: Penebar Swadaya.

Nugroho, H. 2004. Uji Media Tanam dan Naungan Pada Stek Tanaman Kantong Semar. Pontianak. Skripsi. Fakultas pertanian Jurusan Kehutanan Universitas Tanjung Pura. (Tidak dipublikasikan).

Suska, MA. 2006. " Merawat Nepenthes Itu Mudah, Jenis dan Syarat Tumbuh Mesti Klop", Majalah Flora 38, April, Halaman 54-55. 